\title{
Teaching Reform and Practice Exploration of Medical Biochemistry Theory Course
}

Jun Jia

Xinzhou Vocational and Technical College, Xinzhou 034000, Shaanxi, China.

Abstract: Biochemists lack understanding of professional medical knowledge, and clinicians have very little understanding of biochemistry, which makes it difficult to teach medical biochemistry theory. However, with the rapid development of life sciences, the demand for high-quality medical personnel in today's society has also become higher and higher. Therefore, it is necessary to link biochemistry with medicine, and at the same time learn from the teaching concepts of biochemistry, to explore several ways to improve the teaching quality of medical biochemistry theory courses.

Keywords: Medicine; Biochemistry; Teaching Reform

Medical biochemistry covers the structure and function of biomolecules, material metabolism and regulation, and the transmission of genetic information. At the same time, it explains the pathogenesis and the mechanism of action of therapeutic drugs in detail with the knowledge of biochemistry. It is a very important basic subject. For medical students, learning medical biochemistry is not only to meet the requirements of grades and credits, but also to improve their professional skills through the important subject. This subject is very difficult for teachers to teach. While leading students to master the teaching content of medical biochemistry courses, they constantly promote them to explore new knowledge in combination with the knowledge they have learned. There are certain professional thinking. The purpose of this reform is mainly to solve the phenomenon of passive learning and exam-oriented learning, and to meet the requirements of cultivating exploratory and practical talents.

\section{Establish the teaching philosophy of "students as the main body and teachers as the leader"}

Traditional teaching concepts are often teacher-centered. In the teaching process, teachers are the main body of the classroom and play a leading role. Simply put, it is what teachers say and what students learn. This kind of teaching philosophy is not conducive to cultivating students' innovative thinking ability. If students are the main body and teachers are the leading role, students can also participate in the teaching process, which can mobilize students' subjective initiative in learning, cultivate their logical thinking ability and independent thinking ability, so that students can achieve the best learning effect, which will greatly improve the quality of teaching. To give a simple example, the structure of DNA is complex, which is difficult for teachers to explain, and it is difficult for students to understand and remember. But before the explanation, teachers should allow the students to check the relevant knowledge first to find the problems. The teacher will answer their doubts in a targeted manner, and constantly guide them to think, then the students will have a deeper memory of the content of the DNA structure. In this case, not only can students learn clearly, but also they will avoid forgetting knowledge after school.

But sometimes, teachers need also to pay attention to the teaching progress and teaching plan. If the students are the main body and the teacher is the lead, the learning time will be more nervous. Therefore, in the process of teaching,

Copyright $(2020$ Jun Jia

doi: 10.18282/le.v9i6.1298

This is an open-access article distributed under the terms of the Creative Commons Attribution Non-Commercial License

(http://creativecommons.org/licenses/by-nc/4.0/), which permits unrestricted non-commercial use, distribution, and reproduction in any medium, provided the original work is properly cited. 
teachers should pay attention to the organic combination with the traditional teaching mode, and make them complement each other.

\section{Strengthen the combination of basic, cutting-edge clinical knowledge}

The subject of biochemistry is developing very rapidly, so that teachers need to grasp the scientific frontier in time, strengthen the combination of the basic and scientific frontier knowledge, and enrich the teaching content. Because in the teaching process, through the introduction of cutting-edge scientific knowledge, research and results, the students' thinking will be broadened, and the needs of different majors have been taken into account in a targeted manner. At the same time, it will help to improve the students' foundation and teaching effect.

Some clinical-related guided discussions will make the study of biochemistry more meaningful for medical students, and make their learning goals clearer and the learning effect be better. The course of medical biochemistry is not just a basic theoretical knowledge for students to learn by rote, it is a relatively practical course that needs the combination of basic and clinical practice. During the learning process, they realize that the basic theoretical knowledge of learning can be applied in actual clinical practice, which will greatly increase their interest in learning and lay a solid foundation. For example, they can introduce the mechanism of hormones combined with insulin to lower blood sugar.

\section{Strengthen the construction of the teaching team}

The school should select high-quality professional teachers with strong scientific research capabilities, strengthen the construction of a faculty with excellent integrity and ability, and ensure the cultivation of innovative talents with excellent academic performance. Continuously improving the overall political quality of the teaching staff is the key to improving the quality of education is to improve the quality of teachers. Encourage teachers to properly use teaching models and methods, such as the teaching concept of the organic combination of PBL teaching mode and traditional teaching mode, open discussion courses, and gradually develop bilingual teaching. With the globalization of the economy, the demand for talents is not only satisfied with the proficiency of professional knowledge, but also high-quality talents proficient in foreign languages. For medical students, this is a big challenge. For medical schools, bilingual teaching is gradually carried out in accordance with the teaching characteristics of professional courses. As a new teaching method, it helps to increase students' attention, cultivate their interest in learning, expand professional vocabulary and improve their ability to read English documents, thereby deepening the understanding of professional knowledge and consolidating professional foundation. When studying the original English textbooks, teachers can keep abreast of the latest foreign theories and development trends and improve their own quality. Besides, carry out bilingual teaching can benefit both students and teachers a lot.

\section{Reasonable arrangement of teaching content}

Medical biochemistry covers the structure and function of biomolecules, material metabolism and its regulation, and the transmission of genetic information. Appropriate content should be deleted or expanded according to the specific requirements of the major. It enables students to learn the content and curriculum system to meet the needs of life science development while taking into account the special requirements of related disciplines, making the professional knowledge mastered by students more targeted and purposeful, focusing on the combination of breadth and depth. As molecular biology penetrates into various fields of medicine, it helps people to have a deeper understanding of the etiology and pathogenesis of various diseases, and the current molecular hybridization, DNA sequencing and molecular biology techniques used in the diagnosis and treatment of diseases. The course plays a very important role, so in the process of teaching, teachers should focus on introducing this aspect of the content. For the teaching of oral and anesthesia majors, the functions of biological macromolecules can be briefly discussed. The content of sugar metabolism, such as the source and destination of blood sugar, should be explained with emphasis.

\section{Change the assessment method}


Course assessment is an important part of talent training. With the advancement of education reform, the reform of assessment methods has also attracted more and more attention. Traditional course assessment methods are mainly based on written test scores. However, this kind of performance-based assessment model is not conducive to student innovation and practice. Students often learn to cope with the test. In order to change the passiveness of students' learning and the bad phenomenon of exam-oriented learning, and to better reflect the degree of students' acceptance of knowledge, a comprehensive assessment method should be adopted in which theoretical scores account for $70 \%$, and the experimental scores account for 30\%. Among them, theoretical scores are divided into test scores accounting for $70 \%$, and in-process performance scores accounting for $30 \%$. The in-process performance results are mainly to ensure that students can take the pre-class preview, classroom interaction and homework seriously.

\section{Use a variety of teaching methods}

Like the content of the chapter on the transmission of genetic information, if the process of gene replication, transcription, and translation is dynamically demonstrated, this complex and abstract process will become more visual and intuitive, which is more conducive to students' understanding. Therefore, teachers should choose multimedia courseware for classroom teaching, use pictures and animations to make knowledge that is difficult to explain more intuitive. In recent years, the Chaoxing Yaer app has been widely used in college teaching. Teachers can teach the content of the course and publish it on the APP in advance, and students can preview and study by themselves in time. At the same time, teachers post the key points of the class on Chaoxing Yaer after class, and students can review online anytime, anywhere. Similarly, there are MOOC courses. On these platforms, teachers can interact with students and answer questions online anytime and anywhere. It is a good attempt to use these information technologies to teach medical biochemistry, and it is worth applying.

Medical biochemistry is a basic theoretical textbook for medical students. It has a wide range of contents and many knowledge points to be mastered, and a considerable part of the content has a certain degree of difficulty. In the process of teaching, it is necessary to actively discover the problems existing in the students' learning, carry out teaching reforms from multiple angles and methods in a timely manner, enrich the resources of students learning medical biochemistry, and attract the attention of students learning medical biochemistry to improve their self-study effect. The teaching process is a complex and dynamic process. Successful teaching reform practice is conducive to mobilizing students' enthusiasm and initiative in learning, improving students' interest in learning, and changing learning just to take the test. In this case, teachers of medical schools must continue to improve themselves, explore constantly the forefront science, and actively use new thinking, new viewpoints, and new ways to serve medical education and cultivate high-quality creative talents. For colleges and universities, it is necessary to continuously improve teaching methods and continuously carry out educational reforms to ensure that education can learn from other's strengths and be more effective.

\section{References}

1. Gong M, Zhou X, Li S, et al. Application and effect evaluation of TBL and LBL teaching modes in the teaching of biochemistry theory courses. Journal of Chengde Medical College 2018; 35(5): 439-441.

2. Wang X, Wang C, Xu N. The exploration of medical biochemistry experiment teaching mode and its influence on theoretical courses. China Higher Medical Education 2011; (11): 66-67.

3. Tang W, Sun X, Zhu M, et al. Teaching reform and practice of medical biochemistry theory course. Journal of Wuhan Institute of Technology 2009; 31(4): 81-85.

4. Ye J, Liu S, Deng X, et al. Some experience in improving the teaching effect of Biochemistry and Molecular Biology theoretical courses in medical colleges and universities. Journal of Baotou Medical College 2007; 23(2): 196-198. 